\title{
Literatura eta generoa Haur Hezkuntzan: Bizkaiako Haur Eskola baten azterketa
}

\author{
Izarra Aizpurua Barinagarrementeria \\ Gasteizko Irakasleen Unibertsitate Eskola \\ Euskal Herriko Unibertsitatea (UPV/EHU)
}

Gema Lasarte Leonet

Hizkuntza eta Literaturaren Didaktika Gasteizko Irakasleen Unibertsitate Eskola Euskal Herriko Unibertsitatea (UPV/EHU)

DOI: $10.1387 /$ tantak.15553

GAKO-HITZAK: Generoa, haur hezkuntza, parekidetasuna, haur literatura, rolak, ipuinak.

\section{SARRERA}

Historian zehar emakumearen diskriminazioa nabarmena izan da kultura askotan. Xx. mendean herrialde garatuetan berdintasunaren aldeko ahalegin handiak egin baziren ere, maila askotan emakumeak oraindik ere zapalduak dira. Euskal herritarren artean, ostera, emakumeen eta gizonen arteko berdintasuna ia-ia lortuta dagoen ustea zabalduta dago. Egia da badirela berdintasuna bermatzen eta genero indarkeria deuseztatzen saiatzen diren legeak eta plan instituzionalak. Halaber, emakumeek lan merkatuan parte hartzen dute, hezkuntza maila guztietara eta kulturara hel daitezke, eta horrek, zalantzarik gabe, bidean aurrera egitea dakar. Hala ere, egungo parekidetasun formalaren atzean ezkutatzen dena oso bestelakoa da: esaten den horretatik errealitatera alde handia baitago. Datu soziologikoek argi erakusten dute diskurtso hutsean, azalean geratzen den parekidetasuna dela gurea, praktikan genero ezberdintasuna gertatzen delako esparru guztietan eta indarkeria sexista eguneroko kontua dugulako.

Begi bistakoa da indarrean dagoen genero sistemak emakumeei eta gizonei ezaugarri bereizgarri batzuk ezartzen dizkiela. Gorputz jakin bati identitate konkretu bat esleitzeaz gain, identitate horren nolakotasunak zeresana ematen du: femeninotasunaren estereotipo tradizionalari erabat loturik baitago. Hori dela eta, ikerketek erakusten dutenez, nesken eta mutilen arteko harremanak asimetrikoak dira oraindik ere, eta egoera asko abusuan 
oinarrituta daude; gaitasunak, trebetasunak eta bizitza proiektuak generoarekin loturik daude oraindik; curriculum edukietan, emakumeen ekarpenak ez dira ikusten, eta sexismoa eta genero indarkeria nerabeen eta gazteen bizitzen garapenean eragiten ari diren errealitateak dira.

Txikitatik ikasi eta barneratzen dira ezberdintasun horiek. Jaiotzerakoan ditugun organo genitalen arabera, genero bat inposatzen digute, eta emakumezko edo gizonezko gisa klasifikatzen gara jendartean.Transmisio edo barneratze horretan haur literaturak garrantzi handia du, horren bidez rol eta funtzio batzuk helarazten baitira. Horrenbestez, parekidetasuna sustatuko lukeen hezkuntza politika batek, hezkidetza programak hain zuzen, eragin handia izango luke nesken kontrako indarkeria egoerak eragozteko orduan.

Hori jakinda, herri txiki batean gai honek duen trataera nolakoa den aztertzea garrantzitsua dela deritzogu. Hori dela eta, Bizkaiko herri eskola bat hartu dugu ikerketarako. Bertan, Haur Hezkuntzako hiru gelatan zentratu eta bertako literatura aztertuko dugu; izan ere, literatura, jendarte sorkuntzaren espresio eta kultur ekoizpena da. Baina literatura oso kontzeptu zabala denez eta dena aztertzea ezinezkoa zaigunez, ipuinetan zentratu gara, eta ipuinak kontakizun hutsak ez direnez, zer balio transmititzen duten ikertu dugu.

Esku artean dugun artikulu honen ikerketa gaia, beraz, «Generoa Haur Hezkuntzan» da, hezkidetza eta literatura izanik ikerketa bidea. Hala, bada, lau zatitan banatuko dugu artikulua: esparru teorikoa eraikiko dugu lehenik, metodoa bigarrenik, emaitzak hirugarrenik eta amaieran ondorioak azalduko ditugu. Esparru teorikoak hiru bloke nagusi izango ditu: [1] generoa, [2] literatura eta [3] oinarrizko curriculumaren dekretua. Metodoak, bestalde, hiru atal nagusi izango ditu: [1] elkarrizketa sakona irakasleekin, [2] irakasleen ipuin kontaketaren behaketa, genero ikuspegitik eta [3] gelako ipuinen azterketa, generoa kontuan hartuta. Horren ostean, ikertutakoaren emaitzak azaldu eta ondorioak aterako ditugu. Ikerlanaren zabaltasuna zehazteko bidean, gaur egungo irakasleek Generoa eta Literaturaren inguruan duten prestakuntza ikertzeko, arestian esan bezala, Bizkaiko herri ikastetxe bateko hiru irakasle eta haien ikasgelak izan ditugu aztergai. Batetik, haiekin solasean aritu gara; bestetik, nola lan egiten duten aztertu dugu eta, azkenik, erabiltzen dituzten literatur testuak aztertu ditugu. Esan behar da ikerketa hau 2013-2014ko ikasturtean egina dela.

\section{ESPARRU TEORIKOA}

\subsection{Generoa}

Gizon eta emakumeen arteko botere harremana modu ezberdinetan izendatu da mendeen joanean. Horrela, XVIII. mendean emakumearen es- 
kubideen defentsa Mary Wollstonecraftek egin zuen, XIX eta XX. mende artean sufragistak ibili ziren aldarrika eta 1960ko hamarkadan kontzientziazio eta diferentziaren inguruan aritu ziren lanean feministak (Alvarez, 2015). 70eko hamarkadan, emakumeen eta gizonen arteko parekidetasunik eza azaltzeko, patriarkatua edota sexua/generoa kontzeptuak erabiltzen hasi ziren. Horren harira, Kate Milleten aburuz, sexuari eransten zaion esanahi soziokulturalak genero identitate konkretu bat ezartzen du, emakume izatea zer den eta gizon izatea zer den zehaztuz. Eta ez hori bakarrik, emakumea eta gizona harremanetan jartzean, hau da, bi generoak harremanetan jartzean, emakumea menpeko gisa azaltzen da (Millet, 1969).

Identitate maskulinoaren baitan garatzen den identitate femeninoak emakumea bigarren mailan lekutuko du (De Beavoir, 2005). Gizonen nagusitasuna argi eta garbi azalduko da maila batean, pertsonen arteko harremanetan (harreman sexualak barne). Politika sexual horren jatorrian kokatuko du Milletek, hain zuzen, patriarkatua. 1975ean Gayle Rubynek emakumeak bigarren mailan uzteko eta generoa eta derrigorrezko heterosexualitatea ekoizteko erabiltzen diren mekanismo historiko-sozialak aurkitu zituen. Berari zor diogu sexu/genero sistema kontzeptua, bata kulturala eta bestea naturala haren esanetan. Sexu-genero sistema, beraz, eredu patriarkarrean antolaturiko gizarteek berauen ongizatea genero zapalkuntzan oinarritu ahal izateko beharrezkoak dituzten mekanismoek osatuko lukete (Azpiazu, 2012). Hartaz, 1960ko feminismoaren paradigma gailendu eta generoaren kontzeptuaren erabilera hedatu zen hurrengo hamarkadetan. Horren lekuko Genero Ikasketak abiatuko dira 1990eko hamarkadan, eta hauek gorputzek eta jokaerek bat egiten ez dutenean konturatzen dira prozesua naturala izan ordez kulturala dela osoki. Hau da, intersexualen, eta transexuelen existentziak generoaz gain, sexua ere kulturala, soziala eta ikasia dela begi bistan jartzen du (Alvarez, 2015). Sexu/genero sistema kritikatzea ekarri zuen Queer mugimendua sortu zen. Queer teoriek aro modernoko borroka identitarioei kritika egiten diete (feminismoari, gay eta lesbianen mugimenduari), eta aniztasunaren aldarrikapena egiten dute. Generoa gainditu nahi da, emakume femeninoa eta gizon maskulinoa binomioa aukera bakarra ez dela aldarrikatuz. Gizon eta emakume kategoriak ez dituzte onartzen. Honen harira, Butlerrek, sexuari buruz ordura arte zegoen kontzepzioa argitu zuen El género en disputa liburuan. Haren ustetan, sexua generoaren eraikuntza dinamikoaren bitartez eraiki ohi da, eta inolaz ere ez zuen ulertzen gorputzari lotuta egon daitekeen zerbait izaterik. Horrekin hauxe esan nahi du: generoak eraikitzen duela sexua, eta sexua ez dela generoaren eraikuntzarako oinarria. Horrez gain, baieztatzen du kulturari aldez aurretik ezartzen zaion elementu gisa eraikitzen dela sexua. Generoa egintza performatiboaren bidez sortzen den egitate dela agertuz, Butlerren teoriak ekinbide politiko berriak proposatu dizkio agenda feministari. Hartara, Butlerrek generoa perfomance eta parodia gisa esplikatzen du. Butlerrek (2007) esaten du performatibitatea ez dela ekintza bakarra, 
errepikapen eta erritual bat baizik. Gorputz baten testuinguruan naturalizatuz bere efektua lortzen duena. Neurri handi batean kulturalki mantendutako iraupen bezala ulertu behar dena.

Performatibitateaz baliatuz, esan genezake ikasia den oro desikas daitekeela. Hizkuntzak ikasten ditugun modu berean, errepikapenean oinarritutako praktikaren bitartez ikasi ohi dugu gizon eta emakume gisa jokatzen, pentsatzen, mugitzen... Hala, nahi izanez gero, ikasitako hori desikasteko aukera dugu.

Jarraian, Connellen bitartez, genero sistemaren teoria sozialari hurbilduko gatzaizkio. Izan ere, Connellek (1995) generoa harreman sozialen egituraren baitakotzat hartzen du: egitura sozial hori pertsonon ekintzaren eta sistema estrukturalaren arteko lotura konplexu eta historikoa da, eta prozesu baten bitartez sortzen da. Genero ezberdintasuna oinarri hartuta eraiki da errealitatea, eta puntu horretan da garrantzitsua egituraren eta pertsonon ekintzaren arteko lotura aintzat hartzea. Txiki-txikitatik hasten den sozializazio prozesuaren bitartez ikasten dugu ezarritako ordena hegemonikoa etengabe erreproduzitzen; baina, era berean, aldaketarako ateak ere irekitzen dira sozializazio berriei eta praktika berriei esker.

«Genero sistemaren existentziarako erabakigarria da jendarteratze prozesua, eta, horri esker, pertsona bakoitzak txiki-txikitatik barneratzen du sozialki eraikia den errealitatea. Pertsonaren kontzientzia determinatzen duen prozesu bat da sozializazioa» (Santamaria, 2011, 28 orr.). Sozializazio horretan eskolak baditu azken urteotan nabarmen azaldu diren bi kezka nagusi: batetik, generoa indarkeria ikasgeletan ekiditea eta bestetik, identitate aniztasuna geletan bermatzea (Vizcarra, Aristizabal, Lasarte, Alvarez Uria, Ugalde, Zelaieta,... 2015). Honen harira eta feminismoen ibilbidearekin bukatzeko, transfeminismoaz hitz egin beharko genuke, hau da, subjektu feministaren aniztasunaz jabetzeko beharraz. Horren argitan identitate aniztasunaz aritzeko hainbat kontzeptu azaldu beharko genituzke, izan ere, geletan txiki-txikitatik binarismo sexuala haustera letozkeen hainbat identitateen aurrean aurkituko gara: trans, transexualak, trabestiak, transgeneroak. Azken honi helduko diogu, transgeder ingelesezko hitzetik dator eta bi esanahi nagusi ditu, bata murritza eta bestea zabala.

Adiera murritzean, transgeneroa esaten zaio jaiotzerakoan eman zitzaiona ez den genero baten bizi den pertsonari, baina kirurgiaren bidez gorputzaren genero markatzaileak aldatu nahi ez dituenari, ez dituelako gorpuztasun maskulino edo femeninodun estereotipo kulturalak osatu nahi. Hala ere, metodo kirurgiko edo hormonalak erabil ditzake bere gorputza aldatzeko arrazoi kosmetiko, adierazpeneko edo ongizatezkoak direla medio. Adiera zabalak barnean hartzen ditu eredu hegemonikoaren kontraesanen diren pertsona guztiak. Alegia, Mendebaldeko binarismo sexual heteronormatibotik eraikitako gorpuztasun, desira, identitate eta genero adierazpenetan arrakalak sortzen dituzten pertsonok ditu transgenerotzat (Alvarez, 2013, 307 orr.). 
Jendarteratze prozesuan parte hartzen duten agenteak anitzak dira: eskola, familia, lana, komunikabideak, mintzaira, erlijioa... Horiek guztiek modu aktibo batean eragiten dute pertsonen hazkuntza eta garapenean. Horregatik, ezinbestekoa da aztertzea agente bakoitzak zer-nolako mezuak bidaltzen dituen. Jarraian gure intereserako den agentea izango dugu hizpide.

\subsubsection{Eskola}

Hezkuntza sistema jendarteak bere kideen hezkuntzarako eratzen dituen erakunde, eragile eta prozesuen multzoa, eta horien antolakuntza da. Piageten (1983) iritziz, eskolatzeak gauza zehatz batzuk egiten hastea dakar, hau da, haurra gai izango da «pentsamenduari buelta emateko» eta ohartuko da gauzak ez direla «diruditenarengatik» gertatzen, gauzak «benetan zer diren» ohartuko da. Ikasleen garapen genetikotik abiatu behar dela dio: «Ez da ahaztu behar ikasi behar diren eduki guztien interakzioaren bidez pasatuko direla etapa batetik bestera» (Piaget, 1983, 43 orr.). Dena dela, garapen genetikotik hasteak ez du esan nahi haur baten irakaskuntzan kontzeptu abstraktuak sartzeko etapa operatorio formalera iritsi arte «besoak gurutzatuta» itxaron behar denik.

Egun, hezkuntza sistema formalak dira nagusi, pertsonaren hezkuntza ibilbidea guztiz zehazten duten hezkuntza mailak. Hezkuntza formalaren barruan dugu eskola. Txiki-txikitatik joaten gara eskolara; hor, ahalmenak garatuz eta milaka balio barneratuz, jendartean bizitzeko prestatzen gara. Baina ezin esan daiteke eskola eremu neutroa denik sozializazio ezberdintzaileari dagokionez. Kontuan hartu behar da hezkuntza politika erabat baldintzatua dagoela garai historikoaren arabera, tokiaren arabera edota jendartea antolatzeko moduaren arabera. Hala, bada, egungo eskola eredua (hedatuen dagoena) jendartearen isla dela esan daiteke: ikasgelatik at maskulinitate eredua nagusitzen da, eta ikasgela barruan beste horrenbeste gertatzen da. Eredu maskulinoak zeharkatzen du hezkuntza politika, eta hori agerikoa da arauei, balorazio sistemari eta antolaketari erreparatuz gero, besteak beste (Aristizabal, 2010). Horren harira, aipatzekoa da Durkheimen aburuz hezkuntza praktikak ez direla bata bestetik isolaturik dauden egitateak, baizik eta sistema berean elkarturik daudela (Durkheim, 1993).

Bestalde, material didaktikoaren irakaspen moduak erabat arrazionalak dira, eta heziketa afektibo zein sexualaren gabezia ikaragarria da. Eskolaren antolaketa moduak berak ere neskatoen askatasuna eta eragile izaera errotik mugatzen du; espazio nagusia mutikoek hartzen dute eta neskatoak albo batean geratzen dira, adibidez (Vizcarra, 2014).

Halaber, eskoletan erabiltzen diren edukietan ukaezina da gizonezkoek eta emakumezkoek daukaten presentzia desorekatua dela. Horren harira, gogoratu behar da ia ezezagunak direla historian zehar ekarpen handiak egin dituzten emakumeak, eta are ezezagunagoak jendarte justu eta parekide baten alde borrokatu direnak. Albert Einstein, Mahatma Ghandi edo 
beste hainbat izen aipa daitezke, ordea, pertsonaia historiko maskulinoei dagokienez (Santamaria, 2011). Horrez gain, ikerlari feministek betidanik oztopoak izan dituzte beren ikerketa lanak argitaratzeko edo zabaltzeko, eta beren diziplinen barruan ia ez da aipurik ikusten (Arrizabalaga eta Carbonell, 1993). Ez hori bakarrik, aurrerago ikusiko dugun bezala, ikerketaren bidez jasotako emaitzetan ere gizonezkoen presentzia gailentzen da.

Hizkuntza askotan forma neutroa maskulinoa izateak areagotu egiten du emakumearen ikusezintasuna, «bestea» kategoria agerian utziz. Horrez gain, hizkuntzaren bidez positiboa eta negatiboa dena adierazteko, askotan, genero bati lotzen diogun ezaugarriren bat erabiltzen dugu. Euskarari dagokionez, askotan esan ohi da euskarak genero neutrorik ez duen heinean ez dela hizkuntza sexista. Are gehiago, euskara erabiltzeko abantaila moduan aurkeztu izan da argudio hori. Baina ez da egia, euskarari ere berdinberdin eman diezaiokegu erabilera sexista. Esate baterako, puta semea dela esanez gaizkilea dela esateko, edota alua erabiliz tontoa denari deitzeko. Horrenbestez, kontu handiz erabili beharreko elementua da, denon arreta merezi duena.

\subsection{Generoa Haur Hezkuntzan}

Teoria feministak dioen bezala, generoaren araberako banaketak jaiotzen garen unetik hasten gara ikasten. Jaio orduko, ditugun genitalen arabera, sexu bat ezartzen zaigu eta, horren arabera, generoa osatuko duten ezaugarri, rol eta funtzio batzuk. Hau da, ar edo eme garela esaten digute, eta, horren arabera, gizon edo emakume izan behar dugula. Batari edo besteari lotutako ezaugarri sozialak izan ezean, ez gara ongi ikusiak edota normalak izango.

Hezkuntza sistema oraindik ere sexismoaren transmititzaile garrantzitsua da, nahiz eta gauzak aldatuz doazen poliki-poliki (Odriozola, 2007). Sexu bakoitzari esleitzen zaizkion rolen prestakuntzarako, onarpenerako, banaketarako eta barneraketarako lekua izan da eskola historian zehar, eta oraindik ere hala da. Hona hemen adibide batzuk; gai askotan, nesken eta mutilen arteko bereizketa bultzatzen da; adibidez, mutilei ez zaie negar egiten uzten edo zenbait unetan sentiberak izaten, eta neskak ez dituzte animatzen jolastokietako bazterretatik mugitzera. Lehiak, bestalde - onena izan beharra, notarik hoberenak lortu beharra eta kirolean lehenengoa izan beharra - elkartasunaren lekua hartzen du. Bestalde, eskolaurrean irakasle gizonezkoen eredurik gabe hazten dira neska-mutilak, hezkuntza eta zaintza emakumezkoen eskuetan dagoela ikusiz eta ikasiz.

Patriarkatuaren iraupena ahalbidetzen duen hezkuntza eredua dugu gaur egungoa. Jaio orduko gizon edo emakume izateko hezten gaituzte, genero bakoitzari kontrakotasun batean eta ordena hierarkikoan oinarritzen diren rolak egokituta. Ez hori bakarrik, genero rol horiek ezaugarri fisiko 
batzuen arabera ezarri ohi dira; hori dela eta, alua dutenei genero femeninoa esleitzen zaie, eta zakila dutenei, maskulinoa. Hala, bada, dikotomia horretan oinarrituta, egungo hezkuntza ereduak sistema patriarkala erreproduzitzen du. Bereizkeria horrekin hautsi eta estereotipo gabeko hezkuntza sistema bat nahi baldin badugu, hezkidetza da irtenbidea (Moreno, 2013). Hezkidetzaren funtsa, genero irizpide patriarkalei muzin eginda eta balio feministetan oinarrituta, ikasle guztien parekotasunean oinarritutako hezkuntza sistema baita.

\subsection{Generoa eta literatura}

\subsubsection{Zer da haur literatura?}

Haur literaturaren historia egiteko orduan sortzen den lehen galdera honako hau da: zer den haur literatura? Galdera berez nahiko konplikatua da, baina erantzuna sinpletu nahian, haur literaturatzat haurrek egindakoa edo haurrentzat idatzitakoa jo beharrean, haurrek irakur eta uler dezaketena dela ulertu ohi da (Colomer, 2010).

Bernardo Atxagak elkarrizketa batean ondoko hau esan zuen bere haur eta gazte literaturari buruz:

A veces escribo novelas; otras, cuentos o guiones para la radio, o historias como la que se cuenta en Memorias de una vaca, y también escribo poemas, canciones... Lo único que cambia en cada uno de los casos es el público que se sienta en el patio de butacas. Me explico: yo tengo en mi imaginación un pequeño teatro, y ese teatro se llena de gente cada vez que me pongo a escribir. Ellos son mis interlocutores, ellos son los que escuchan lo que yo voy escribiendo y me dan, o no, su beneplácito. Pues, como digo, esa gente que asiste a las lecturas no es siempre la misma. Algunos son fijos, sin embargo. Por ejemplo, Foster, el novelista inglés. A Foster, lector exigente y con ideas muy inteligentes acerca de la literatura, siempre le siento en el teatro, se trate de un cuento infantil o se trate de un guión radiofónico. Sólo le dejo salir cuando se trata de una letra para un grupo pop; creo que Foster no está especialmente interesado en este tipo de cosas. Cuando escribí Memorias de una vaca, una fila entera del teatro estaba llena de estudiantes de 13, 14 ó 15 años... (Atxaga 1992 in Etxaniz 1996, 17 orr.)

Juaristik, aldiz (Juaristi in Etxaniz 1996, 15 orr.), honako hau dio haur literaturari buruz: «Helduak bezala tratatu behar dira haurrak, eta helduak balira bezala idatzi. Kodea aldatu behar duzu, hori bai, eta modu ulergarrian eman. Kontatzeko modua aldatzen da». Juan Cerverak, ostera (Cervera 1990 in Etxaniz 1996, 16 orr.), honela definitzen du haur literatura: «Haurra edo gaztea hartzaile (ez derrigorrez helburu) duen eta hitza artistikoki darabilen manifestazioa». 
Horrenbestez, haur literatura, oro har, honela defini daiteke: haurtzaroan dauden pertsonek irakurtzen dituzten liburuak, haientzat aproposak edo atsegingarriak direnak. Eta hasieran esan dugun bezala, honetatik guztitik atera daitekeen ondorioetako bat hauxe izan liteke: haur eta gazte literatura zer den definitzeko orduan hartzailea izan behar dugula kontuan. Hartzaileak dituen jarrera eta ezaugarriengatik ere abiatu behar da kontzeptua zehazterakoan. Baina hartzailea zein den eta nolakoa den ere kontuan izan behar da.

Hari horri jarraiki, W. H. Auden-ek (1974) dioenez (Auden in Etxaniz 1996), liburu bat haurrentzat ona bada helduentzat ere ona izango da, baina ez alderantziz. Ideia hori beti presente izan behar da haur eta gazte literaturaz hitz egiteko orduan; izan ere, haur eta gazte literatura ez da haurrek edo gazteek irakurtzen, ulertzen eta disfrutatzen duten literatura; haiek ere irakur, uler eta goza dezaketena baizik.

\subsubsection{Generoak haur literaturan duen eragina}

Haur literaturan izugarrizko garrantzia du generoak; izan ere, literaturaren bidez hainbat rol helarazi daitezke, eta umeek dena irensten dute. Protagonistak aztertuz gero, begi bistakoa da gehienak maskulinoak, irakurlearen adinekoak eta ikasleak direla (Colomer, 2010). Protagonista femeninoek, ostera, irakurlearen amaren adina izan ohi dute, etxekoandreak izan ohi direlako. Ondorio gisa, esan daiteke haurren jendarteratze prozesuko bi agenterik garrantzitsuenak - familia eta eskola - emakumeen esku daudela. Horrez gain, bestelako senideren bat agertuz gero, anaia, osaba, aitona edo lehengusuak izan ohi dira gehienetan. Arreba, amona, izeba edo lehengusinen beharrik ez da egoten, amak betetzen duelako horien hutsunea (Gabiria, 2001).

Halaber, segituan ohartuko gara gehienak mutilak izateaz gain, argiak, bizkorrak, inteligenteak, bihurriak... direla, eta erabakiak hartzeko abilezia dutela. Jardunari dagokionez, bestalde, mutilek askoz jarduera gehiagotan parte hartzen dutela esan beharra dago. Neskak ikasle soil gisa ageri dira, eta mutilak, berriz, ikasleak izateaz gain, abokatuak, printzeak, arotzak edo alkateak izan ohi dira gehienetan. Amak etxekoandreak izaten dira batik bat, eta sukaldean agertzen dira; aitak, bestalde, noizbait sukaldean ageri badira ere, bestelako lan bat izaten dute. Aipatzekoa da ipuinetako mutil gehienak abenturazaleak direla; neskak, berriz, maitasun kontuetan ibili ohi dira. Neskak gehiago maitemintzen dira, arduratsuagoak dira eta zalantza eta kezka gehiago izan ohi dute (Gabiria, 2001).

Haur literaturan ilustrazioak duen garrantzia aparta da, eta zenbait kasutan, testua baino sexistagoa da. Izan ere, sexuen arteko rolak askoz ere modu argiagoan ikusten dira marrazkien bidez, hitzen bidez baino. Ipuinetako azalari erreparatuz gero, mutilak agertzen dira gehienbat. Bada aipagarria den beste ideia bat ere: askotan, ilustratzaileek sexua zehazten ez ba- 
dute ere, inkontzienteki sendagileak, psikologoak, kazetariak, postariak eta antzeko pertsonaiak agertzen direnean, joera handia dago mota horretako pertsonaiak maskulinotzat hartzeko

80ko hamarkadan eztabaida zabal bat planteatu zen literatura tradizionalaren inguruan; ahozko ipuinen inguruan, zehazki. Kritiko batzuen ustez, ipuin horiek oso karga ideologiko handia dute: bai politikoki, klase banaketa dela eta (errege, laborari, aitoren seme edo alaba..., klase horien arteko mugak eta klase banaketa hori ontzat ematen delako); bai gizarte mailari dagokionez (emakumearen rola, esaterako). Kritiko horien ustez, horrelako ipuinak oso klasistak eta matxistak dira. Baina, bestalde, badaude beste ikerlari batzuk ipuin horien alde onak goraipatzen dituztenak; Bettelheim (1977) eta Henche (2008) dira horietako bi. Bettelheimen ustez, ipuin tradizionalek bestelako balio batzuk ere transmititzen dituzte (laguntasuna, eskuzabaltasuna, elkarrekin lan egitea...) eta, gainera, ipuinok haurraren garapenerako oso baliagarriak eta iniziazio funtzioaren bultzatzaile direla defendatzen dute. Henchek (2008), aldiz, esplikatzen du arketipoez eraikiak daudela eta arketipoak modu inkoszientean jasotako esperientzia kolektiboak direla, eta oso bestelakoa dela denboraren joanean arketipo horiek estereotipo bilakatu izana, ipuinaren jatorria ezabatuz, eta istorioen irakurketa sexista nahiz klasista bilakatuz.

Folklorea berreskuratu behar dugu, herriaren jakituria gureganatu, baina, ikusi dugun bezala, kontu izanik literatura guztiak transmititzen duen ideologiarekin, nahita edo nahi gabe, aktiboki edo pasiboki (Etxaniz, 1996; Lasarte, 2012).

\subsection{Oinarrizko curriculumaren dekretua}

Ikastetxeetan irakasten diren materiekin loturiko curriculum ofizialak eta ezkutuko curriculumak1 funtsezko eragina du neska-mutikoen genero sozializazioan, hau da, gure jendartean gizon izatea eta emakume izatea zer den adierazten die, zein den espazioa (publikoa, pribatua), rolak, sexu bakoitzari zer jokabide eskatzen zaion eta zer jokabide diren desegokiak. Bada, ageriko eta ezkutuko curriculumean sexu bereizkeria nabaria da, eta ageriko curriculuma alda dadin, izugarrizko ahalegina egin behar da ezkutuko curriculumean.

Otsailaren 18ko 4/2005 Legeak, Emakumeen eta Gizonen Berdintasunerakoak2, 29. artikuluan dioenez, Hezkuntza Administrazioak hezkidetzako proiektuak sustatuko ditu, eta jarraian aipatzen diren hezkidetza

1 Ezkutuko curriculuma: hezkuntza prozesuan modu inplizituan transmititzen diren ezaguerak, jarrerak eta balioak adierazten ditu. Jarrera inkontzienteak, ikusten zailak. (Eusko Jaurlaritza, 2013: 13).

2 EHAA, 2005eko martxoaren 2ko 42. zenbakian argitaratua. 
helburuak integratuko ditu hezkuntzako maila ezberdinetako jakintza arloetako eta diziplinetako curriculumaren diseinuan eta garapenean.

Martxoaren 22ko 3/2007 Lege organikoa, 24. artikuluan, gizonen eta emakumeen arteko berdintasun eraginkorra lortzeari buruz ari da. Honela dio berdintasun printzipioa hezkuntza politikan barneratzeari buruzko bigarren atalak:

Hezkuntza administrazioak emakumeei eta gizonei hezkuntzarako eskubide bera bermatuko die, tratu berdintasunaren printzipioa modu aktiboan barneratuz, hezkuntza helburu nahiz jardueretan, eta emakumeen eta gizonen artean desberdintasunak sortzea saihestuz, jokabide sexistengatik edo halakoekin zerikusia duten gizarte estereotipoengatik. Hezkuntza administrazioek, euren eskumenen esparruan, helburu horri begira, hurrengo jarduerak gauzatuko dituzte:

a) emakume eta gizonen arteko berdintasunari buruzko printzipioaren inguruan arreta berezia jartzea curriculum eta hezkuntza etapa guztietan, b) jokabide nahiz eduki sexistak eta emakumeen eta gizonen artean bereizkeria sortzen duten estereotipoak ezabatzea eta ezestea, batez ere, testuliburuetan eta hezkuntza materialetan.

Azkenik, Eusko Jaurlaritzak Hezkuntzari buruzko 2/2006 Lege organikoan (2006ko maiatzaren 3koa) xedatutako curriculuma aztertuz gero, ikus daiteke generoak ez duela trataera berezirik. Inguruaren Ezaguera izeneko esperientzia eremuko «Kultura eta bizitza gizartean» blokean ageri da soilik generoaren aipamena; eta honela dio: «Mutikoen eta neskatilen artean harreman orekatuak ezartzea. Zenbait estereotipo eta aurreiritzi sexista identifikatu eta gaitzestea».

\section{HELBURUAK}

Ikergai honi helburu hau ezarri zaio [1] generoak ikaskuntzan duen garrantzia eta presentzia nolakoa den antzemateko lagin txiki bat ikertzea: hain zuzen, Bizkaiko herri ikastetxe bateko hiru gela. Horretarako lagin hori osatu duten irakasleak elkarrizketatu dira, erabiltzen duten literatura aztertu da eta, azkenik, irakasle bakoitzak ipuin bat nola kontatzen duen behatu da, gelan generoaren kudeaketa nolakoa den ikusteko asmoz.

\section{METODOA}

Ikertu dugun eskola 1.300 biztanle inguruko herri batekoa da, eta bakarra da herrian. Ikastetxean, aurtengo ikasturtean, 109 ikasle daude; lan- 
gileak, berriz, hogei dira (jantokiko bost langileak eta garbitzailea barne). Bertan, Haur Hezkuntza eta Lehen Hezkuntza eskaintzen da, eta zerbitzua osatzeko, txikientzako haurtzaindegia ere eskolan bertan dago. Horretaz gain, jantoki eta garraio zerbitzua ere eskaintzen du eskolak, eta baita eskolaz kanpoko hainbat ekintza ere, Guraso Elkarteak antolatuta. Berdintasunaren inguruan irakasleek egindako inolako lan edota inolako argitalpenik ez dago, baina aurtengo kurtsoan, elkarbizitza planaren barruan, hezkidetza lantzen hasi dira. Haur Hezkuntzako gelei dagokienez, esan behar da ez dutela metodo jakinik erabiltzen; Giltza argitaletxeko materiala dute, baina eredu moduan erabiltzeko. Izan ere, irakasleak erabakitzen du zer material eta nolakoa erabili.

\subsection{Erabilitako metodologiak eta diseinaturiko tresnak}

Ikerlan hau egiteko, metodo kualitatiboa hartu dugu oinarritzat; izan ere, metodo horrek errealitate sozialaren esanahi eta sinboloak ulertzeko aukera eskaintzen du, zuzenean parte hartzaileengana hurbilduz eta haien pertzepzio osoa aztertuz (Bisquerra, 2004). Metodo kualitatiboaren barruan, sakoneko elkarrizketa eta ipuin kontaketen behaketa izan dira erabilitako teknikak eta, hala, ahozko hizkuntzaren eta gorputz adierazpenaren bitartez, irakasleen errealitate konkretua ezagutzeko parada izan dugu. Bi erreminta erabili dira, beraz, elkarrizketa eta behaketa.

Elkarrizketari ekingo diogu. Elkarrizketa egiteko, hiru irakasle hautatu dira, eta aldez aurretik prestatutako galdera sorta bat erabiliz jaso da hirurei buruzko informazioa. Galdera sorta hamahiru galdera irekik osatzen dute, eta, horri esker, informazio oparoa bildu ahal izan dugu. Era berean, parte hartzaileek generoari buruz duten diskurtsoaren bidez iritsi gara praktika sozialak ezagutzera. Ikasgelako irakasleak aurrez aurre elkarrizketatu ditugu. Hiru bloke nagusi bereizi ditugu galderetan: [1] generoari buruzko galdera multzoa, [2] literaturari buruzkoak eta [3] generoak eta literaturak rolekin duten lotura. Elkarrizketa osorik irakurtzeko (ikus 1. Eranskina). Gidoia egituratzeko orduan, lehenik eta behin irakasleek generoaren inguruan duten informazioa eta teoria jakin nahi izan dugu; bigarrenik, marko teorikoari jarraiki, literaturaren inguruan duten informazioa eskuratu nahi izan dugu eta azkenik, bi gai nagusiak uztartu ditugu. Jakin nahi izan dugu literaturaren irakaskuntzan generoaren zenbaterainoko erabilpena egiten duten.

Bigarrenik, eta metodologia kualitatiboarekin jarraikiz, jakin nahi izan dugu elkarrizketatuek, bakoitzarentzat finkaturiko denbora eta ekintza jakin batez, gelan generoa nola kudeatzen duten ipuin kontaketa dela medio. Horretarako, hiru irakasleak banan-banan ipuin bana kontatzen entzun ditugu, eta bitarte horretan hainbat alderdi aztertu ditugu. Aldez aurretik taula bat osatu dugu, eta bertan finkatu dugu zer den aztertu 
beharrekoa. Izan ere, behaketa horretan bi bloke nagusi hartu ditugu kontuan: [1] bata, irakasleak ipuina kontatzeko orduan generoaren inguruan egin duen trataera, eta, [2] bestea, bitarte horretan nesken eta mutilen parte hartzea nola kudeatu duen. Hala, behaketa parte-hartzailearen bidez, praktika zuzenean aztertzeko aukera izan dugu, eta horri esker, irakasle-ikasleen jardunaren berri xehetasun handiagoz jakin dugu. Behaketan lau kontu behatu dira, lehenik, ipuin estereotipatuak erabiltzerakoan generoaren trataera nolakoa izan den; bigarrenik, hizkuntza sexistaren erabilpenik egiten duen irakasleak; hirugarrenik, nesken eta mutilen artean parte hartzea orekatua dagoen, eta ezezko kasuan, irakasleak egoera nola kudeatu duen (ikus 2. Eranskina).

Sakoneko elkarrizketaz eta behaketaz gain, metodo kuantitatiboan ere oinarritu gara (Cea D'Ancona, 1998). Horrenbestez, beste erreminta bat sortu dugu ikerturiko literatur testu guztietan genero kudeaketa nola gertatzen den modu kuantitatiboan aztertu ahal izateko. Atal honetan ipuinak izan dira aztergai; izan ere, geletako ipuin guztiak bildu eta banan-banan aztertuz datu zehatzak atera ditugu. Corpusa aukeratzeko orduan gelan erabiltzen dituzten ipuin guztiak izan ditugu kontuan, 87 ipuin guztira. Ikerketa kuantitatiboa ezinbestekoa iruditu zaigu erabiltzen den materialak genero asimetria areagotzen duen jakiteko. Irakasleriaren formazioaren inguruan galdetu dugu elkarrizketaren erreminta erabiliz, eta haren formazioa behatu dugu behaketaren erremintaren bidez, baina formakuntza bezain inportantea da geletan erabiltzen den material didaktikoa, kasu honetan ipuinak. Emaitza horiek ateratzeko, taula bat osatu dugu, eta taula horretan txertatu ditugu ipuinen analisirako kontuan hartu beharreko puntuak zeintzuk diren. Itemak osatzerakoan [1] pertsonaia maskulinoen eta femeninoen agerpenak kuantifikatu dira, eta [2] betetzen dituzten funtzioak eta rolak zehaztu dira, eta ilustrazioekin ere gauza bera egin da. [3] Istorioan zehar protagonismoa nork hartzen duen zehaztu da eta baita zer lotura duten espazio publiko nahiz pribatuekin ere. Geletako ipuinak sexistak diren aztertzeko hogei galderaz osatutako taula bat erabili dugu. Galdera hauetan bai edo ez erantzunez, edota esatekoren bat izanik aipamenen laukitxoan idatziz osatu da. Galdera hauek erreferentzialtasuna lantzeko eta biltzeko aukeratu dira. Batetik, emakumeak kuantifikatu nahi izan dira eta era berean euren protagonismoa. Bestetik, rol eta estereotipoak dauden ikusi nahi izan da eta horrenbestez ezinbestekoa izan da euren ezaugarrien inguruan galdetzea: ausardia, arrakasta, politika, espazioen kudeaketa ezinbesteko galderak izanik (ikus 3. Eranskina).

Behin hori eginda, jasotako emaitzekin grafikoak egin ditugu, eta hor modu ikusgarrian islatu dugu bildutako emaitza. Beste modu batera esanez, geletako ipuinek generoaren ikuspegitik zer trataera duten azaldu dugu grafiko horien bidez. 


\subsection{Parte hartzaileak}

Erabilitako erremintak zehaztu ondoren, parte hartzaileei buruz hitz egitea dagokigu. Hasteko, esan behar da, ikerketarako aukeratutako ikastetxean Haur Hezkuntzako lau gela daudela; hain zuzen, bi, hiru, lau eta bost urtekoen gelak. Bi urtekoen gelan hamahiru ikasle daude; hiru urtekoen gelan, hamalau; lau urtekoen gelan, bederatzi, eta bost urtekoenean, hamaika; berrogeita zazpi ikasle guztira. Arestian esan dugun bezala, hiru dira gure parte hartzaileak: bi, lau eta bost urtekoen gelako irakasleak. Hauek dira elkarrizketatuen ezaugarriak:

K1 deituko zaion irakaslea bi urtekoen gelako tutorea da, emakumea da, eta gelan hamahiru ume daude; horien artean, zazpi neskak dira, eta sei, mutilak. K2 deituko zaion irakaslea ere emakumea da. Lau urteko ikasleekin dago bera, eta bederatzi ikasle ditu guztira: bi neska eta zazpi mutil. K3 deituko diogun irakaslea ere emakumea da. K3-k bost urteko hamaika ikasle ditu, eta hor ere, K2-ren gelan bezala, mutilak gailentzen dira: zortzi mutil eta hiru neska daude.

\section{EMAITZAK}

Metodologian azaldu dugun bezala, hiru tresna erabili dira ikerketa bera aztertzeko. Hala, bada, emaitzetan ere, metodoan aipaturiko hurrenkera erabiliko dugu. Lehenik, elkarrizketaren emaitzak adieraziko dira; bigarrenik, irakasleek ipuina kontatzeko orduan generoa nola kudeatzen duten, eta hirugarrenik, geletan erabiltzen dituzten ipuinen azterketa egin dugu, genero ikuspegitik.

\subsection{Elkarrizketaren bidez: irakasleak generoari buruz duen prestakuntza eta jarduna}

Emaitzak analizatzerakoan hiru elkarrizketatuek esandakoa triangelatu da. Horrela, galdera erantzunak kategorizatu dira. Kategorizazio hau modu kronologikoan interpretatu da. Erantzun bateratuak sintetizatu dira. Erantzunetan azaldutako nabardurak izan dira ahots gisa jaso direnak. Esan behar da ez dela analisirako programarik erabili, erantzun bakoitzaren erantzun sintetizatua eta triangelatua baizik. Beraz, elkarrizketaren emaitzak oso modu orokorrean analizatu dira.

Elkarrizketarekin hasteko, irakasleei galdetu genien zer ezagutza duten gizonen eta emakumeen aukera berdintasuna bultzatzeko neurriei buruz, eta neurri horietan zer-nolako parte hartzea izan duten; galdetu genien, halaber, generoaren inguruan nolako prestakuntza duten eta parekidetasuna bultzatzea garrantzitsua iruditzen zaien. Denetariko erantzunak jaso genituen. 
Ez daukat prestakuntza berezirik generoaren inguruan. Nire bizipenak eta ezagutzak kontuan izanda, nire pentsamendua eta jarrera dut, eta garrantzitsu deritzot parekidetasuna bultzatzeari. (K1)

K2-k, aldiz, esan zigun ez duela generoaren inguruko prestakuntzarik; hau orain dela gutxi zabaldutako moda dela, lehen elkarbizitza zen bezala. Orain dela urte batzuk elkarbizitzari eman behar izan ziotela indarra, eta gaur egun, berriz, berdintasunari. Dena den, landu behar dela iruditzen zaiola esan zigun, eta, gainera, goitik datorren agindua denez landu beharra daukatela. Baina denerako astirik ez dagoela zioen. Izan ere, horretarako trebatu beharra dagoela iruditzen zaio, formaziorik gabe, bera behintzat, zenbait gauzaz ez delako jabetzen. K3-k ere ez du prestakuntza berezirik generoaren inguruan, baina berdintasunari buruzko edukiak lantzea komeniko litzatekeela pentsatzen du, eta horretarako zenbait aukera daudelakoan dago.

Alde batetik, guraso, irakasle zein ikasleentzat lantegiak egitea komeni da, eta baita hezkidetzari buruzko ikasgai bat izatea ere. Beste aukera bat litzateke zeharka lantzea, hau da, hezkidetzari buruzko puntu bat egotea, zeregin ezberdinetan ikusita gehiago barneratzen dela esaten baitute. Niri azken hori gehiago gustatzen zait; izan ere, eraginkorragoa delakoan nago. Horrenbestez, une oro berdintasuna bultzatzen saiatzen naiz, edonolako gaiak, adibideak, ipuinen hausnarketak, ikasleek esandakoaz edo bestelako zenbait ekintzaz baliatuz. (K3)

Berdintasuna lantzeko zer-nolako ekintzak egiten dituzten eta zer eduki jorratzen dituzten galdetu genienean, K1-ek azaldu zigun ez duela ekintza berezirik egiten, eta, egunerokoak kontuan izanik, berdintasuna egunero bultzatzen saiatzen dela. Era berean, klasean gaia tratatzea ezinbestekoa dela iruditzen zaio, eta eskolak jendartea aldatzeko duen erantzukizuna izugarria dela aitortu zuen, eta bera irakaslea den aldetik eredu ere badela zioen. Horrez gain, alor horretan gabezia handia eta kontzientzia gutxi antzematen duela esan zigun, eta, alde horretatik, sentsibilizazio beharra ikusten duela. Bera sentsibilizatuta dagoela esan zigun, eta baita beste irakasle batzuk ere. Jendartean lortu beharreko helburua dela uste du, eta, eskolari dagokionez, hezkidetzako eskola izan beharko litzatekeela. Horrez gain, argi utzi zuen oraindik lan asko dagoela egiteko.

Era berean, esan zigun berak ikasle guztiak, neska edo mutila izan, modu parekidean tratatzen dituela. Genero estereotipoak asko antzematen dituela ere azaldu zigun, baina erabiltzen duten materialaren bidez eta jartzen dituzten adibideen bidez estereotipoak ez direla indartzen baieztatu zuen. Edukiei dagokienez, aldiz, azaldu zigun gelan bi urteko ikasleen edukiak lantzen dituztela eta bera ahalegintzen dela eduki horiek berdintasunean oinarrituta egon daitezen, baina berez edukiak ez daudela berdintasunean oinarrituta. K2, ostera, saiatzen da generoa kontuan izaten, baina 
beste gauza guztiei adinako inportantzia emanez, dena baita garrantzitsua beretzat.

Giltza bildumako edukiak jorratzen ditugu, eta oso gustura gaude; gainera, ipuineko protagonista maskota bat da, eta ikasleek gelan dute maskota hori eta etxera eramateko aukera dute. (K2)

Ikasleak parekideak izan daitezen saiatzen naiz, eta jorratzen ditugun edukiak Giltza bildumakoak dira. (K3)

Ikasgelan eta ipuinak kontatzeko orduan generoa aintzat hartzen duten galdetu genien, K1-ek esan zigun bere ikasgelan generoa kontuan hartzen dela eta berdintasunean oinarritutako ipuinak erabiltzen dituztela. Gainera, azaldu zigun iazko kurtsoan eskolako ipuin guztiak banan-banan aztertu zituztela genero ikuspegitik egokiak ziren edo ez jakiteko. Ipuin, olerki, abesti edota bestelako zerbait gustuko ez duenean edo egokia ez dela uste duenean moldatu edo baztertu egiten duela ere esan zigun. K2-k esan zigun beti saiatzen dela berdintasunean hezten. K3-k ere aintzat hartzen duela esan zigun; momentuan bururatzen zaizkion galderak egiten dizkiela ikasleei, horren inguruan gogoeta egin dezaten; esate baterako, beraien etxean nork josten duen eta halako galderak egiten dizkiela. Horrez gain, edozein aukera aprobetxatzen duela zioen, eta askotan ikasleen komentarioek bultzatzen dutela horrelako galderak egitera.

Hauxe izan zen irakasleei egin genien hurrengo galdera: Zeintzuk dira eskolan egon daitezkeen diskriminazio egoerak? Galdera horri K1-ek erantzun zigun soilik. K2-k eta K3-k ez zekitela esan ziguten.

Ikasleak oso txikiak direnez, esan daiteke oraindik ez direla genero diskriminazioaren kontziente. Era berean, beraien artean ez dute inolako desberdintasunik sortzen; denak dira berdinak; denak jolas berdinetan jolasten dira, eta oraindik ez daukate barneratuta sexu desberdintasuna. Horrenbestez, ez nuke esango egoera diskriminatzailerik dagoenik ikasgelan, eta, egonez gero, hor nago ni hori mozteko. Eta, azken batean, gelan ikusten ditudan gabeziak oro har gizartean ikusten ditudan berberak dira. (K1)

Ipuinetan zentratuz, ondoko galderak egin genizkien: Zer ipuin kontatzen diezu ikasleei? Zeuk asmatzen dituzu edo asmatutakoak erabiltzen dituzu? Moldatzen dituzu, zerbait gustuko ez baduzu? Nolako ipuinak dituzte gustukoen ikasleek? Hirurek esan zuten ez dutela ipuinik asmatzen. Edonolako ipuinak erabiltzen dituztela; denetariko ipuinak gustatzen zaizkiela haurrei, eta, zerbait gustuko ez dutenean, moldatu egiten dutela.

Nahiz eta ez zaidan gustatzen eta ados ez nagoen, esan behar dut literatura oraindik ere sexista dela, jendartea oraindik ere halakoa delako. Eta horri aurre egiteko, beharrezkotzat jotzen dut honetan sinestea, norberak sinesten ez badu, sentitzen ez badu, barrenean ez bada- 
rama, hala behar duela pentsatzen ez badu... ezer gutxi egin baitaiteke. Gela honetako materiala parekidea izan dadin saiatzen naiz, eta eredu batzuk gutxika-gutxika aldatuz doaz; barikuetan, esaterako, abesti hau kantatzen dugu: Barixeku, amantalak etxera. Zertarako? Aitak garbitzeko (bis). Abestia neuk moldatu dut, lehen «amak garbitzeko» baitzion abestiko hitzak. Beste olerki batean ere egin dut aldaketa; izan ere, olerkiak «gizona traktore gainean» zioen, eta gizon hitzaren ordez emakume jarri dut; hori bai, irudia ez nuen aldatu, eta irudian gizonezkoa ageri da. (K1)

Gustuko dut ipuinak kontatzea, eta asmatzeko joerarik ez badut ere, moldaketak egiten ditut. (K2)

K3-k esan zigun ez duela ipuinik asmatzen, ez duelako horretarako gaitasunik, eta nahiago lukeela gaitasun hori izango balu. Era berean, argitu nahi izan zuen ipuin tradizionalen bukaerak tristeak iruditzen zaizkiola, eta horietan egin izan dituela moldaketak, baina ikasleen laguntzaz: bukaera ezberdinak asmatzeko eskatzen die ikasleei. Horrenbestez, ipuina dagoen moduan kontatzen diela esan zigun, batzuetan zertxobait moldatuta, baina oso gutxi; normalean, dagoen moduan irakurtzen die. Nahiz eta ipuinak dioenarekin edo transmititzen dituen balioekin ados ez egon, dagoen moduan kontatzen diela azaldu zigun, errealitatea zein den erakusteko. Dena den, ipuina bukatu ostean galderak egiten dizkiela adierazi zigun, ea ados dauden ipuinak dioenarekin, ongi begitantzen zaien..., galderen bidez hausnarketa egitera bultzatuz. Halaber, esan zigun ipuin tradizionalak erabiltzea gustuko duela; nahiz eta oso estereotipatuak diren eta rol bereizketa handia dagoen gure antzinako ondaretzat dituela eta balio ugari transmititzen dituztela uste du. Azaldu zigun horregatik kontatzen dizkiela ikasleei ipuin horiek eta gero gaur egungo bizimoduarekin alderatzen dituztela. Honela jarraitu zuen K3-k:

Bestalde, ipuinak sexistak izan ez daitezen hainbat ezaugarri izaten ditut kontuan horien hautaketa egiteko garaian: besteak beste, izenburuari, gizonezkoen eta emakumezkoen presentziari, erabiltzen dituen aipuei eta irudiei garrantzi handia ematen diet. Era berean, emakumezkoek eta gizonezkoek ipuinean duten rol banaketa eta rol horien ezaugarri positibo eta negatiboak aintzat hartzen ditut, pertsonaien itxura fisikoari eta janzkerari erreparatzen diot, eta pertsonaien intelektualtasuna eta afektibotasuna aztertzen dut. Gainera, literaturan azaltzen diren balioak egilearen ikusmiran barneratuta dau3de. Eta ni sexismoaren kontrako borrokarekiko sentikorra naizenez, era naturalean hori transmititzen duten narrazioak hautatzen ditut. (K3)

Gero, hizkuntzaren erabilerari buruz galdetu genien: ea neska eta mutilak berdin tratatzen ahalegintzen ziren. Hirurek baietz erantzun zuten. Elkarrizketa bukatzeko, galdetu genien ea zer gabezia antzematen duten eskolan, ikasgelan eta haurrengan, eta zer gustatuko litzaiekeen aldatzea. 
K1-ek kalean ikusten duen arazo bera ikusten du gelan. K2-k, ostera, ez du arazorik ikusten ikasleengan:

Pentsatzen dut ez dela batere erraza eguneroko bizimoduan teoria eta praktika uztartzea eta haurrei berdintasunaren gaia nola irakatsi asmatzea. Gelan agertzen diren estereotipoekin zaila egiten zait nola jokatu asmatzea, eta gauza bera gertatzen zait espazioaren erabileran nesken eta mutilen artean egon ohi den desorekari aurre egiteko garaian. Askotan, kontziente naiz mutilek leku handietan eta neskek txikietan agintzen dutela, eta neskak espazio horietatik botatzen dituztela, eta, halakoetan, saiatzen naiz jarrera horiek mozten, baina beti ez dut asmatzen. (K2)

K3-k, bestalde, zaila ikusten du haurrek etxetik ekartzen dituzten hainbat uste eta jokaera aldatzea. Ondorioz, horri aurre egiteko, gizonen eta emakumeen arteko berdintasunari buruzko formazioa jasotzea beharrezkoa dela ikusten du, batez ere irakasleen hasierako formazioan. Honela esanez bukatu zuen:

Baina bagabiltza zerbaitetan. Hezkidetza lantzeko zenbait jarduera egitea pentsatzen gaude datorren kurtsorako, nahiz eta hasiera batean aurtengo kurtsoan lantzea pentsatu genuen. Gainera, udalarekin batera gaude gai honetan, eta elkarlanean zenbait ekintza egin ditugu, eta aurrerantzean egiteko asmoa dugu. (K3)

\subsection{Behaketa: irakasleak ipuinak kontatzen}

Lehen behaketa K1 irakaslearen ipuin baten kontaketan oinarritua dago. Irakasle horren eskutik, Susaeta editorialeko Arkume maitagarriak ipuina (1999) entzuteko aukera izan genuen, Bob Bampton egile eta ilustratzailearena.

1. taula

Arkume maitagarriak ipuin kontaketaren behaketa

\begin{tabular}{lccr}
\hline & BAI & EZ & TARTEKA \\
\hline $\begin{array}{l}\text { Nahiz eta ipuina estereotipatua izan, moldake- } \\
\text { tak egiten ditu? }\end{array}$ & $\mathrm{X}$ & & \\
$\begin{array}{l}\text { Hizkuntzaren erabilera sexista du? } \\
\text { Nesken eta mutilen parte hartzea orekatuta }\end{array}$ & $\mathrm{X}$ & $\mathrm{X}$ & \\
dago? & & \\
Ez baldin badago, orekatzen saiatzen da? & $\mathrm{X}$ & \\
\hline
\end{tabular}


Hasteko, gela horretan entzun genuen ipuinari buruz ezer gutxi esan dezakegu. Izan ere, ipuinak, generoaren aldetik, ez zuen ezer kritikatzeko; hori dela eta, ez genuen izan generoaren aurrean nola erantzuten duten ikusteko aukerarik. Bestalde, esan beharra dago ipuinarekin interesatuta azaldu zirela haurrak, eta ez zitzaien zaila egin arreta mantentzea. Ezagutzen zuten ipuina, eta irakasleak haien parte hartzea bultzatu zuen. Gainera, nesken eta mutilen parte hartzea nahiko orekatua zen; nahiz eta neska batek erantzuten zien galdera gehienei, irakasleak esku hartu eta parte hartzea orekatzen zuen.

Bigarren behaketa K2 irakaslearen eskutik entzundako Euria ari duenean (2010) ipuinaren kontaketan dago oinarrituta. Ipuinaren egilea eta ilustratzailea Leire Salaberria da, eta editorea, Pamiela etxea. Ipuin horrek haurrentzako albumak sortzeko V. Etxepare Saria jaso zuen 2011n.

Ipuin kontaketa honetan, antzematen zen irakaslea oso gustura ari zela ipuina kontatzen, eta baita dohain aparta duela ipuinak kontatzeko ere, batez ere umorea baliatzen duelako. Era berean, ikasleekin duen konfiantza lagungarri zaio; ikasleak eroso sentitzen ziren berarekin, eta ipuina entzuteko interesa erakutsi zuten. Izugarri bereganatu zuen gure arreta ere, eta oso gustura egon ginen kontatzen zuena entzuten, baina, era berean, ikusi genuen kontatzen ari zen ipuina nesken eta mutilen arteko ezberdintasunean oinarritzen zela eta bera ez zela horren jabe. Ez hori bakarrik, ipuineko rol, irudi eta hitzak normaltzat jotzen zituenez, naturaltasun osoz kontatzen zuen ipuina, eta ikasleek hori dena modu naturalean jasotzen zuten.

Hori dela eta, ez zuen aldakuntzarik egin ipuinean. Halaber, irakasleak protagonista mutila zela uste zuen -ipuina bukatzean esan zigun - , baina neska zen - ez zuen izenik - eta estereotipo guztiak hausten zituen - piraten kapitaina zela amesten zuen, eta ekaitza gustuko zuen, ez zen beldurtzen - . Ipuineko beste zenbait komentario sexista eta estereotipaturekin ez zen ohartu ere egin, eta aldaketarik egin gabe kontatu zituen; adibidez, honelakoekin: «bitartean, amatxo etxean txakurra garbitu eta garbitu ari zen»; «ama haserretuko da euria ari duenean leihoa irekitzen dudala ohartzen bada»; «autoan sartu, eta aitak eraman ninduen eskolara». Horrez gain, ikasleen parte hartzea ez zen orekatua, eta irakasleak ez zuen ezer egin hori aldatzeko. Ezberdintasun horiek barneratuta zeuzkala ikus zitekeen, eta, normaltzat jotzen zituenez, ez zen ohartzen. Izan ere, mutilek soilik parte hartu zuten ipuinean, eta protagonistak piratekin amesten zuela entzutean egundoko interesa piztu zitzaion mutikoetako bati, eta honela galdetu zuen: «Piratekin egiten du ametsetan?», «baina lotan dagoela egiten du ametsetan?». Beste mutiko batek ere komentario bat egin zuen irakaslea ipuina kontatzen ari zela: «Bai, mutilak mutilekin eta neskak neskekin». Komentario horretaz jabetu zen irakaslea, baina berandu samar, eta zer erantzun ez zekiela geratu zen. 
2. taula

Euria ari duenean ipuin kontaketaren behaketa

\begin{tabular}{lccc}
\hline & BAI & EZ & TARTEKA \\
\hline $\begin{array}{l}\text { Nahiz eta ipuina estereotipatua izan, } \\
\text { moldaketak egiten ditu? }\end{array}$ & $\mathrm{X}$ & \\
$\begin{array}{l}\text { Hizkuntzaren erabilera sexista du? } \\
\text { Nesken eta mutilen parte hartzea orekatuta } \\
\text { dago? }\end{array}$ & $\mathrm{X}$ & $\mathrm{X}$ \\
Ez baldin badago, orekatzen saiatzen da? & $\mathrm{X}$ & \\
\hline
\end{tabular}

Hirugarren eta azken behaketan, K3 irakasleak kontatutako Bai argazki moñoñoak (2010) ipuinaren kontaketan oinarritu gara. Liburu horren egilea José Antonio Francés da, eta ilustratzaileak Mónica González López, Paz Montalbón Turón eta Luis Valardell Panicot.

Esan bezala, K3-k Bai argazki moñoñoak ipuina hautatu zuen ikasleekin lantzeko. Neska-mutilak lurrean eseri ziren bere aurrean zirkuluerdi bat osatuz, eta jarrita zeuden moduari erreparatuta soilik, ikus zitekeen zenbaterainoko eragina zuen generoak. Izan ere, hiru neskak elkarrekin jarri ziren, eta mutil guztiak ere elkarrekin. Irakasleak libre utzi zien, eta ez zuen esku hartu. Kontatu zien ipuina ez da estereotipatua, eta bere hartan kontatu zien, hau da, irakurri egin zuen. Begi bistakoa zen nesken eta mutilen parte hartzea ez zegoela batere orekatuta. Hiru neskak adi-adi zeuden, eta irakaslearen galdera guztiei erantzuten zieten. Mutilak, ostera, bi izan ezik, nekatuta zeuden, eta ez ziren arreta mantentzeko gai izan; albokoarekin hizketan ari ziren. Irakasleak hor esku hartu zuen; errepikapenez baliatu zen, haurren euskalkian laburpen txikiak egin zituen -K1-ek eta K2-k ez bezala, K3-k euskara batuan kontatu zien ipuina-, eta mutil horiei galderak egin zizkien, horrela guztien parte hartzea orekatzeko asmoz. Aipatu behar da neska baten parte hartzea izugarria izan zela; izan ere, ipuina ezagutzen zuen. Irakasleak hor ez zuen esku hartu, eta gertatuko zenaren berri ematen uzten zion noiznahi. Esan behar da gela horretara, beste bi geletara ez bezala, arratsaldez joan ginela eta hori asko igarri zela haurrek arreta mantentzeko garaian. 


\section{3. taula}

Bai argazki moñoñoak ipuinaren kontaketa

\begin{tabular}{lccc}
\hline & BAI & EZ & TARTEKA \\
\hline $\begin{array}{l}\text { Nahiz eta ipuina estereotipatua izan, moldake- } \\
\text { tak egiten ditu? }\end{array}$ & & $\mathrm{X}$ \\
Hizkuntzaren erabilera sexista du? & & $\mathrm{X}$ & \\
$\begin{array}{l}\text { Nesken eta mutilen parte hartzea orekatuta } \\
\text { dago? }\end{array}$ & $\mathrm{X}$ & \\
Ez baldin badago, orekatzen saiatzen da? & $\mathrm{X}$ & & \\
\hline
\end{tabular}

\subsection{Gelan erabiltzen dituzten ipuinak sexistak dira?}

Ondorengo lerroetan literaturara hurbilduko gara, baina hori oso kontzeptu zabala izaki, literaturako zati txiki bat hartuko dugu soilik aztergai: ipuinak, hain zuzen. Besteak beste, Haur Hezkuntzan asko erabiltzen direlako eta egundoko garrantzia dutelako rol eta estereotipoen transmisioan. Horretarako, Haur Hezkuntzako lau gelatako ipuinak aztertuko ditugu banan-banan, hau da, K1-en, K2-ren eta K3-ren gelako ipuinak, 87 ipuin guztira, eta grafikoen bidez agertuko dugu emaitza (Ikus 4. Eranskina).

K1-ek gelan dituen hogeita bederatzi ipuinak hartu eta aztertu genituen. Bi motatako ipuinak ditu, berak ikasleei kontatzen dizkienak - horietako hamabi zituzten - eta ikasleek beraiek ikustekoak - hamazazpi-. Azaldu zigun bezala, hilabete bakoitzean gai bat lantzen dute, eta gai horrekin lotura duten ipuinak kontatzen ditu. Horrez gain, ikasleren batek bestelako ipuinen bat kontatzeko eskatzen badio edota etxetik ipuinen bat ekartzen badu, horiek ere kontatzen dituela argitu zigun.

K2-ren gelan hogeita hiru ipuin dituzte, eta horietatik bederatzi dira irakasleak kontatzen dituenak. Hezkuntza sistema unitateka lantzen dutenez, irakasleak kontatzeko zituen ipuin guztiak unitate horren ingurukoak dira, Giltza. Tik-Tak. 4 urte. 6. unitatea bildumakoak. Ipuin horietako protagonista Rufus maskota da. Maskota hori gelan dute, eta asteburuetan ikasle batek eramaten du berarekin etxera. Gainontzeko hamalau liburuak ez ditu irakasleak kontatzen, ikasleentzat dira, ikusteko dituzte. Era berean, esan behar da irakasleak kontatzen dizkien ipuinak ere eskura dituztela noiznahi beraien kabuz ikusi nahi izanez gero.

K3-ren gelan hogeita hamabost ipuin dituzte. Horietatik hamaika irakasleak kontatzen dizkie, eta, K2-ren gelan bezala, Giltza. Tik-Tak. 5 urtekoen bilduma erabiltzen dute. Ipuin horietan ere protagonista maskota bat 
da, eta asteburuetan ikasle batek etxera eramaten du. Era berean, aipatzekoa da hiru ipuin tradizional ere badituztela.

Halaber, beste hogeita lau liburu txiki dituzte nahi dutenean bat hautatu eta etxera eramateko. Liburu horiek Ibaizabal argitaletxekoak dira. Fonemak modu alaian eta atseginean ikasteko baliagarria den liburu multzoa da. Idazlea Miren Artetxe Hormaetxea da. Eta ilustratzailea, Mónica Conde Ortiz. Umoreaz baliatzen dira, ondo pasatuz ikastea baita helburua. Ipuin horietan antzematen da genero bereizkeria dagoela.

Gela bakoitzean dauden liburuen aurkezpena eginda, orain, liburu guztiekin eginiko ikerketaren emaitzak azaldu ditugu. Horretarako, bost grafiko aukeratu ditugu. Lehenik eta behin, jakin nahi izan dugu protagonista emakumezkoek izenik baduten, izenak izana baitu. Bigarrenik, garrantzitsua dela iruditu zaigu aztertzea ipuinetan etxeko lanak nork egiten dituen. Hirugarrenik, maitasuna nola tratatzen den aztertu da. Laugarrenik, lagunekin irteten diren pertsonaiak nortzuk diren aztertu dugu. Eta, bosgarrenik, pertsonaiek darabiltzaten koloreak zeintzuk diren aztertu dugu.

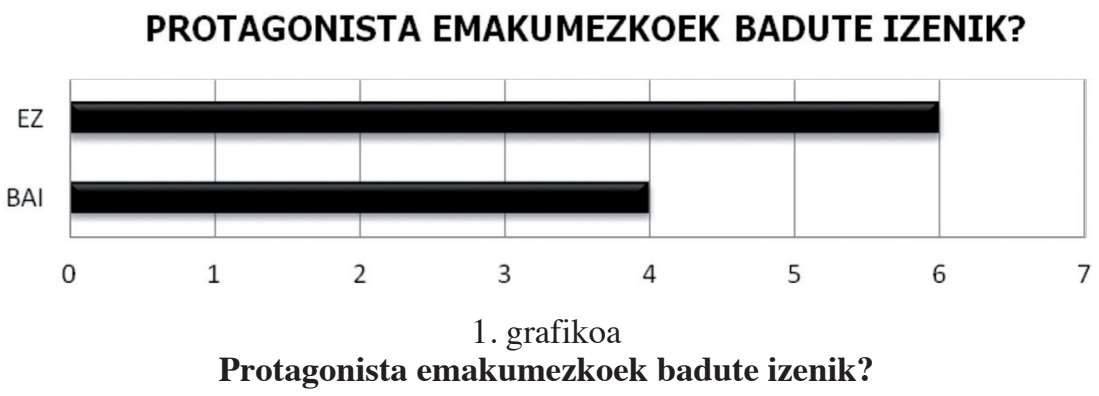

Ipuinetako protagonistak aztertu ondoren, portzentaje handiena gizonezkoak direla ikusi dugu: \%70 inguru. Gainontzekoak dira soilik emakumezkoak, eta emakumeetatik \%60k ez dute izenik, eta sexua ez da zehazten idatzian, ilustrazio bidez soilik ikusten da emakumeak direla. Protagonista ez diren pertsonaiekin ere gauza bera gertatzen da; nahiz eta protagonistetan baino portzentaje altuagoa bete pertsonaia emakumezkoek, ez dago orekatuta: \%40 inguru dira emakumezkoak eta \%60 gizonezkoak.

Faktore hori hiru geletan gertatzen da, eta irakasleak kontatzen dituen ipuinetan gutxiago gertatzen bada ere, presente dago. 


\section{ETXEKO LANETAN}

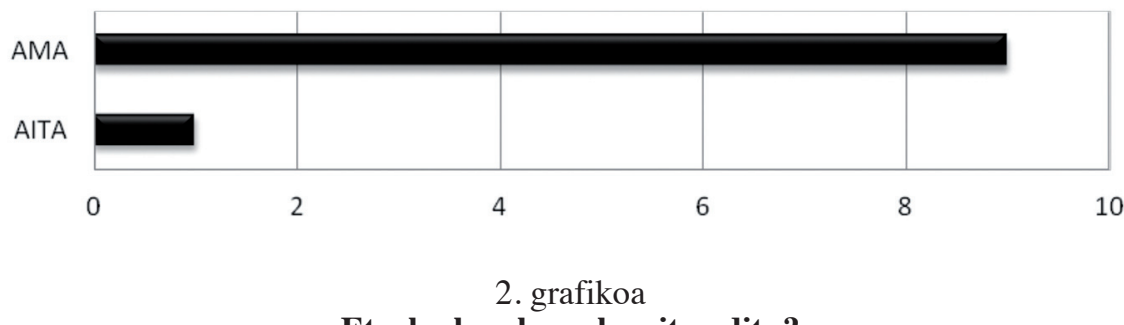

Etxeko lanak nork egiten ditu?

Grafiko horrek etxeko lanen ardura noren esku dagoen adierazten du. Ipuinen \%90ean emakumeen esku dago etxeko lana. Era berean, gizonen ardura beste zerbait dela islatzen da; hain zuzen, etxetik kanpoko lana egiten dute edota bestelako arduraren bat betetzen dute; esaterako, haurrak autoz nonbaitera eraman. Seme-alaben kasuan horren argi ikusten ez bada ere, \%60 neskak dira etxeko lanetan laguntzen dutenak.

Bi sexuek betetzen duten rolari erreparatu diogu, eta argi dago etxeko lanetan emakumezkoaren presentzia gailentzen dela ia-ia \%100ean. Izan ere, ikasleentzat diren ipuin guztietan ikus liteke amonaren, amaren eta alabaren esku dagoela etxeko beharra. Era berean, faktore honetan esan behar da badagoela aurrerapauso txiki bat, zeren irakasleek darabilten bilduman ikusten da, nahiz eta etxeko lanetan emakumezkoek jarraitzen duten, semealaben kasuan orekatuago dagoela, hau da, \%60 inguru alabak dira etxeko lanetan dihardutenak eta \%40 inguru semeak.

\section{MAITASUN ERROMANTIKOA BULTZATZEN DA?}

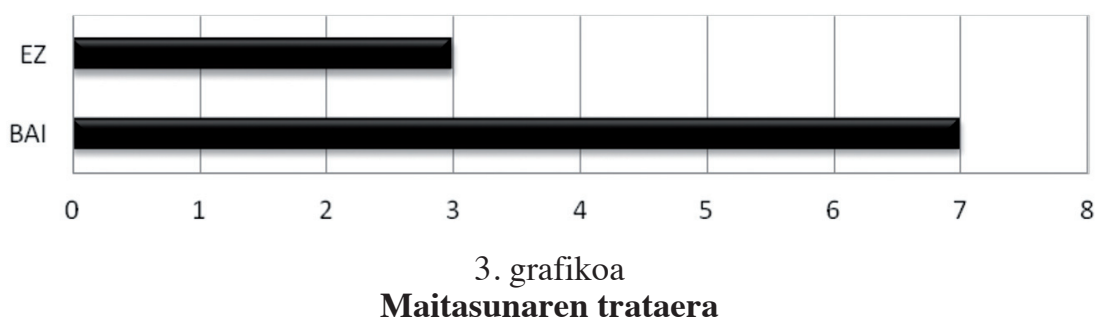

Maitasunaren gaia jorratzen duten ipuinen \%70ek maitasun erromantikoa bultzatzen dute. Hein handi batean, ipuin tradizionalek sustatzen dute maitasun erromantikoaren iraupena, ipuin horien \%100en ildo nagusia maitasun erromantikoa baita. Era berean, ikasleek ikusteko dituzten 
zenbait ipuinetan ere maitasun eredu hori gailentzen da, eta horixe da betiko estereotipoak sustatzen dituzten faktore handienetako bat; izan ere, horren baitan egituratuta dauden ipuinek izugarrizko rol banaketa bultzatzen dute.

\section{LAGUNEKIN IRTETEN DIRA}

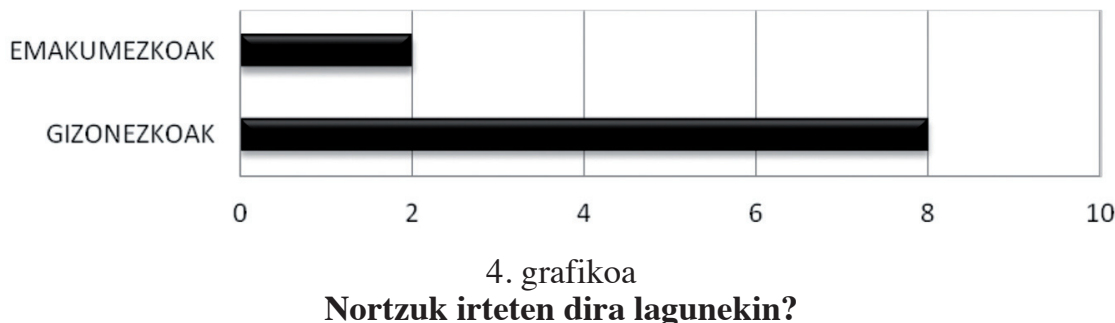

Nortzuk irteten dira lagunekin?

Grafiko honek lagunekin irteten diren pertsonaiak gizon edo emakume diren azaltzen du. Hala, lagunekin irteten diren pertsonaien \%20 soilik dira emakumezkoak; gainontzeko \%80a gizonezkoak dira. Horren arrazoia garbia da: esan dugun bezala, emakumeak etxeko lanetan dihardute; hori dela eta, modu inplizituan islatzen bada ere, oso nabarmena da barru espazioa emakumeari dagokiola, eta kanpokoa, gizonari. Honetan, Katxiporreta bildumako ipuinei buruz esan behar da modu parekidean lantzen dutela espazioen erabilera zein rolen banaketa.

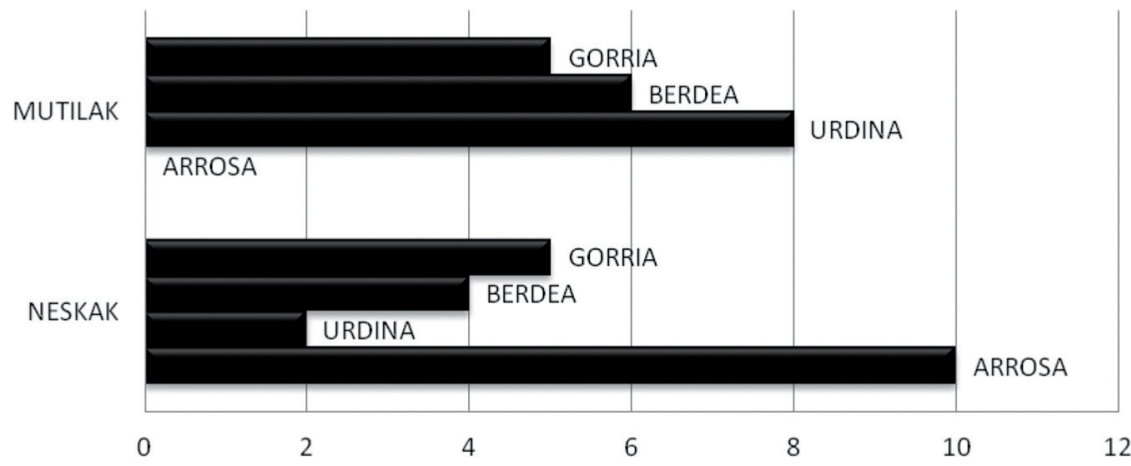

5. grafikoa

Zer kolore darabilte neska-mutilek? 
Grafiko honek neska-mutilek darabilten arroparen kolorea zein den adierazten du. Lehen begiratuan, ikusten da kolore arrosa neskek bakarrik erabiltzen dutela. Kolore urdinari dagokionez, gehienbat mutilek darabilte; nesken $\% 20$ soilik janzten dira kolore urdinez. Aipagarria da neska batzuk urdinez jantzita ikusi ahal izatea baina mutilik batere ez kolore arrosarekin. Berdearen kasuan ere, mutilak gailentzen dira, \%60k baitarabilte, eta nesken $\% 40 \mathrm{k}$. Kolore gorria, aldiz, orekatuta dago, maila berean baitarabilte neskek eta mutilek. Aipatzekoa da pertsonaiak ez neska eta ez mutil direnean, hau da, animaliak direnean, koloreen erabilera mantentzen dela genero bereizketa egiteko; baina arropen kolorearen bidez egin beharrean, azal kolorearen bidez egiten da.

\section{ONDORIOAK}

Irakasle elkarrizketatuen arabera, hezkidetzarako formazioa eta kontzientzia nahitaezkoa dira ikasleak modu parekidean tratatu ahal izateko. Esandakoa baieztatu da klaseak aztertzeko orduan; ikusi da K1 eta K3 irakasleek badutela gaitasun aski ipuin sexistak egokitzeko, eta, era berean, nesken eta mutilen parte hartzea modu orekatuan kudeatzeko, baina K2-k zailtasunak izan ditu material didaktikoa erabiltzeko orduan eta baita umeen parte hartze orekatua bermatzeko orduan. Hori dela eta, ondoriozta daiteke K1-ek eta K3-k formazio eta parekidetasun kontzientzia handiagoa dutela K2-k baino eta ondorioz gela nahiz materialak kudeatzeko orduan hezkideago dela bere jarduna

Bestalde, gelan erabiltzen dituzten ipuinei dagokienez, begi bistakoa da protagonista gehienak maskulinoak direla (Gabiria, 2001). Ikertutako ipuinetan, ikusi dugu emakumeen protagonismoa urria dela, protagonisten $\% 30$ inguru soilik baitira emakumezkoak. Ez hori bakarrik, protagonista emakumezko horietako $\% 60 \mathrm{k}$ ez dute izenik. Horrez gain, etxeko lanetan aritzen diren pertsonaien \%90 emakumezkoak dira. Bestalde, maitasunaren inguruko ipuinei dagokienez, $\% 70$ maitasun erromantikoan oinarritzen dira. Azkenik, esan behar da hezkuntza sistema sexismoaren transmititzailea dela oraindik, gauzak poliki-poliki aldatuz badoaz ere (Odriozola, 2007). Halaber, ipuin horiek azaltzen dituzten rol eta estereotipoak aztertu ondoren, emakumezkoen $\% 20$ soilik irteten dira lagunekin.

Beraz, ondorio orokor gisa, esan daiteke eskola horretan ikerturiko irakasle gehienen kezka dela hezkidetza; irakasleek aho batez azaldu dute hezkidetzan formatzeko beharra dagoela. Halaber, behar hori berretsi ahal izan dugu irakasleak ipuinak kontatzeko orduan egin dugun behaketan. Azkenik, erabiltzen dituzten ipuinetan ikusi da emakumeen erreferentzia oraindik urria eta estereotipatua dela literatur testuetan. Horrekin esan nahi da hezkidetzarako kontzientzia eta nahia badagoela, baina formazioa eta 
materiala berrikustea eta eguneratzea aski inportantea dela aztertutako eskola honek ikasleak modu parekidean hez dezan (Vizcarra, Aristizabal, Lasarte, Alvarez Uria, Ugalde, Zelaieta, ... 2015).

Esan behar da eskola txiki bateko Haur Hezkuntza aztertu dela, irakasleekin elkarrizketa sakona eginez, horiek lana nola egiten duten behatuz eta erabiltzen duten material didaktikoa ikertuz, genero ikuspegitik betiere. Lagina oso txikia da ondorio orokorrak ateratzeko, eta hobetzeko proposamena hortxe dago: lagina handitzea eta zabaltzea. Ikerketa honen ekarpenik nagusiena, ordea, eskolan genero asimetria detektatzeko erabili dituen hiru erremintetan dago; izan ere, metodologia kuantitatiboa eta kualitatiboa batu ditu lagin txiki hori aztertu ahal izateko.

\begin{abstract}
In this research, we studied how the topic of «gender» is treated in a little village. To complete the research, we focused in three kindergarten classrooms of the village school. We studied the literature used in the classrooms, because it is the expression of the creativity and some restrictive values are possible to be found in it. As the literature subject is a very extent theme and impossible for us to study it all, we just focussed on the stories. Stories never are just stories, all of them have values; and in this research we studied the values that are transmitted within each story. To continue with this research, some aims were assigned to the study. Firstly, a theory frame was built to know the importance and presence of the topic of gender in the learning process. Then, to be able to study a sample, the teachers who created the sample were interviewed. In that interview, the type of literature they used was analysed. Finally, in order to find out how the teachers use the topic of gender in the classroom, each teacher was observed using a specific method whilst they were telling a story. Once all the data was collected, the results were portrayed. At the end of the research, to conclude it accurately, you can find the general conclusions.
\end{abstract}

Keywords: The gender, childhood education, equality in education, children's literature, short stories, roles.

Esta investigación analiza el tratamiento de género en un pueblo pequeño. Para ello, la escuela de dicho pueblo, y especialmente 
las aulas de Educación Infantil, representan el contexto de la investigación; se ha analizado la literatura que se utiliza en las mismas, teniendo en cuenta que dicha literatura, siendo la expresión de la creación social y cultural, puede aparecer salpicada de valores excluyentes. Sin embargo, teniendo en cuenta que la literatura es un concepto demasiado amplio y que, por tanto, resulta imposible analizarla en su totalidad, nos hemos centrado en los cuentos infantiles y en el análisis de los valores que estos transmiten. Respecto a los objetivos de la investigación, en primer lugar se ofrece un marco teórico orientado a analizar la presencia e importancia que el género muestra en el proceso de enseñanza-aprendizaje; posteriormente, se ha entrevistado a docentes, se ha analizado la literatura que utilizan y, por último, se ha realizado una observación sistemática de la forma en que dichos docentes narran los cuentos infantiles, prestando especial atención a la gestión del tratamiento de género. Una vez recopilada toda la información, se presentan los resultados obtenidos. Como conclusión general se afirma que tanto la formación del profesorado como la utilización de materiales didácticos adecuados, son imprescindibles para la consecución de una escuela coeducada.

Palabras clave: género, Educación Infantil, literatura infantil, roles, cuentos.

Dans cette recherche, nous avons étudié comment le thème de «genre» est traitée dans un petit village. Pour compléter la recherche, nous nous sommes concentrés dans trois classes de maternelle de l'école du village. Nous avons étudié la littérature utilisée dans les salles de classe, car il est l'expression de la créativité et des valeurs restrictives sont peut trouver en elle. Histoires jamais ne sont que des histoires, ils ont tous des valeurs; et dans cette recherche, nous avons étudié les valeurs qui sont transmises dans chaque histoire. Pour poursuivre cette recherche, certains objectifs ont été assignés à l'étude. Tout d'abord, un cadre théorique a été construit pour connaître l'importance et la présence de la question de genre dans le processus d'apprentissage. Ensuite, pour être en mesure d'étudier un échantillon, les enseignants qui ont créé l'échantillon ont été interrogés. Dans cette interview, le type de la littérature qu'ils ont utilisé a été analysé. Enfin, afin de savoir comment les enseignants utilisent le thème de l'égalité dans la salle de classe, chaque enseignant a été observée en utilisant une méthode spécifique tandis qu'ils racontent une histoire. Une fois toutes les données ont été recueillies, les résultats ont été dépeints. A la fin de la recherche, de conclure avec précision, vous pouvez trouver les conclusions générales. 
Mots-clé: Le genre, l'éducation de la petite enfance, l'égalité dans l'éducation, la littérature pour enfants, histoires courtes, les rôles.

\section{ERREFERENTZIAK}

Alvarez, Uria,A. (2004). Euskara eta diskriminazio sexuala. Jakin, (142), 47-62.

Alvarez, Uria,A. (2013). Glosategia. Genero-ariketak. Retolaza, I. eta Castillo, I. (ed). Donostia: EDO.

Alvarez,Uria, A. (2015). Identitate eta harreman sexual/generikoen aniztasuna. Gasteizko

Ikastetxeetan (0-18 urte) hezkidetza egoerari buruzko diagnosi azterlana. Gasteizko Udala.

Aristizabal, P. (2010). Emakume eta gizonen berdintasuna irakasleen formazioan: Gasteizko Irakasle Eskolaren kasua. Bilbo: EHU/UPV.

Azpiazu, J. (2012). Gizon taldeak eta maskulinitate berriak. EHU/UPV (argitaratu gabea).

Beauvoir, S. (2005). El segundo sexo. Madril: Cátedra.

Bettehleim, B. (1978) El psicoanálisis de los cuentos de hadas. Madril: Crítica.

Bisquerra, R. (2004). Metodología de la Investigación cualitativa. Madril: La Muralla.

Butler, J. (2007). El género en disputa: El feminismo y la subversión de la identidad. Bartzelona: Paidós.

Cea D’Ancona, M. A. (1998). Metodología cuantitativa: Estrategias y técnicas de investigación social. Madril: Síntesis.

Colomer, T. (2010). Introducción a la literatura infantil y juvenil. Madril: Síntesis.

Connell, R. W. (1995). Gender and Power: Society, the Person, and Sexual Politics.

Cambridge: Polity Press.

De Beauvoir, S. (2005). El segundo sexo. Madril: Cátedra. Feminismos.

Durkheim, É. (1993). Hezkuntza eta soziologia. Bilbo: Klasikoak, D.L.

Etxaniz, X. (1996). Euskal Haur eta Gazte Literaturaren Historia. Gasteiz: UPVEHU.

Fernandez, I. (2010). Maitasuna nerabeen arteko genero sozializazio prozesuetan. Ikerketa lana, 2010eko irailean (ikergai honetan autoreak emandako bertsio bat erabili dugu).

Gabiria, J. (2009). Haur literaturako rolak eta gizarte eredu berriak. Emakunde, $75(1), 12-1$.

Henche, I. (2008). Educar en valores a través de los cuentos. Argentina: Bonum.

Hezkuntza-sisteman hezkidetza eta genero-indarkeriaren prebentzioa lantzeko Gida Plana (Eusko Jaurlaritza, 2013) http://www.hezkuntza.ejgv.euskadi.net/ r43-2459/eu/contenidos/informacion/dig_publicaciones_innovacion/eu_conviven/adjuntos/coeducacion/920006e_Pub_EJ_hezkidetza_plana_e.pdf orrialdetik. 
Ibarra, J. (2004). Genero haremanak hedabideetan.Barnetiko begirada bat. Generoa, Sexua, Hedabideak. Errealitateak, estrategiak, utopiak. Ihardunaldiak. Abril, N. (Koord). 73-75 Emakunde: Gasteiz.

Lamas, M. (2002). «La antropología feminista y la categoría género», en Cuerpo, Diferencia Sexual y Género, Mexiko: Tauruz.

Lasarte , G. (2013). Teaching how to Look at and View Bodies within Literature. Education. 1. zkia. 3. 105-112.

Legea: 23. 4/2005 Otsailaren 18koa, Emakumeen eta Gizonen Berdintasunerakoa (2002ko martxoaren 2ko EHAA).

Lege Organikoa: 21. Martxoaren 22ko 3/2007, Emakumeen eta Gizonen Berdintasun eragingarrirako (2007ko martxoaren 23ko EAO, 71. zk.).

Lege Oraganikoa: 2/2006 Maiatzaren 3koa, Hezkuntzari buruzkoa. (EAO, maiatzaren 4koa)

Millet, K. (1969). Política sexual. Balentzia: Catedra Puv.

Moreno, M.A. (2013). Queremos coeducar. Centro de Profesorado y recursos de Aviles-Occidente.

Odriozola, X. (2007). Gizonezkoen sexismoa, maskulinotasuna eta askapena.

Donostia. 2014ko uztailaren 10ean berreskuratua https://heterodoxia.files.wordpress.com/2007/11/sexismoaetagizonenaskapenapdf.pdf orrialdetik.

Piaget, J. (1983). A dónde va la educación. Bartzelona: Teide.

Rubin, G. (1989). Reflexionando sobre el sexo. Notas para una teoria radical de la sexualidad. In C.

Vance (Arg.), Placer y peligro. Explorando la sexualidad femenina. Madril: Revolución.

Santamaria, A. (2011). Maitasun erromantikoa. Argitaratu gabea. 2014ko ekainaren16an berreskuratuta,http://topatu.info/wpcontent/uploads/2013/03/maitasun_erromantikoa_ainara_santamaria5.pdf orrialdetik.

Sau, V. (1981). Diccionario ideológico feminista. Bartzelona: Icaria.

Vizcarra, M. T. (2014). Gorputza eta generoa gorputz heziketan. In Gorputza eta generoa.

Teoria, didaktika eta esperientziak. Lasarte, G., eta Alvarez, A. (ed). UEU.

Vizcarra, M.T, Aristizabal, P., Lasarte, G., Alvarez Uria, A., Ugalde, A., Zelaieta, E...(2015). Gasteizko Ikastetxeetan (0-18 urte) hezkidetza egoerari buruzko Diagnosi azterlana. Gasteizko Udala.

\section{ERANSKINAK}

\section{Eranskina: ELKARRIZKETA}

Galdetegia irakaslearen ideietara hurbiltzeko sortu dut, horrela, interesatzen zaidan gaiaren gaineko usteak, kezkak, zein ezagutza-maila jasotzeko. Ondorengoak dira galdetegia osatzen duten dimentsioak edo azterketarako unitateak: 


\section{IKASTETXEA}

Zenbat ikasle daude eskolan?

Zenbat langile?

\section{GELAREN ETA BERTAKO PARTE HARTZAILEEN DESKRIBAPENA}

Zure gelan zenbat ikasle daude?

Zenbat neska? Eta zenbat mutil?

Zutaz aparte beste irakaslerik egoten da beraiekin?

Ikasleen jatorria nongoa da?

Ama hizkuntza zein dute?

Nolako ikasleak dira?

\section{ELKARRIZKETAUAREN ARGAZKI OROKORRA}

Zenbat urte dituzu?

Ze ikasketa duzu?

Noiztik zaude BHI-n?

Zertan pasatzen duzu aisialdi denbora?

Hartu duzu noizbait ikuspegia feminista lantzeko militantzia esparruren baten parte?

\section{NOLAKO PRESTAKUNTZA DUZU GENEROAREN INGURUAN?}

- Nolakoa da gizon eta emakumeen aukera berdintasuna bultzatzeko neurrien ezagutza eta neurri horietan izan duzun parte hartzea? Nolako prestakuntza duzu generoaren inguruan? Garrantzitsua deritzozu parekidetasuna bultzatzea?

- Egunerokotasunean emakumeen eta gizonen berdintasunari buruzko edukiak jorratzen dituzu?

- Zeintzuk dira eskolan egon daitezkeen balizko diskriminazio egoerak?

- Zein gabezi antzematen duzu eskolan, ikasgelan eta haurrengan? eta zer gustatuko litzaizuke aldatzea?

- Berdintasuna lantzeko zer-nolako ekintzak egiten dituzu?

- Gainontzeko irakasleek badute gizon eta emakumeen berdintasunari buruzko edukiak lantzeko asmorik? Eskolan emakume eta gizonen Berdintasun Plana egiteko beharra eta parte hartzeko prest egongo ziren?

- Badago gizon eta emakumeen berdintasunaren inguruan irakasleek egindako lanik edota argitalpenik? 
- Generoa aintzat hartzen duzu gelan? Eta ipuinak kontatzerakoan?

IPUINAK

- Zein ipuin kontatzen diezu ikasleei?

- Zeuk asmatzen dituzu edo asmatutakoak erabiltzen dituzu?

- Moldatzen dituzu, zerbait gustuko ez baduzu?

SEXISMOA HIZKUNTZAN

- Hizkuntzari dagokionez, ahalegintzen zara trataera bera eskaintzen sexu biei?

\section{Eranskina: LEHEN BEHAKETA FITXA: IRAKASLEEN IPUIN} KONTAKETA AZTERTZEKO TRESNA

LIBURUAREN IZENBURUA:

EGILEA:

ILUSTRATZAILEA:

\begin{tabular}{l}
\hline BAI $\quad$ EZ TARTEKA \\
\hline $\begin{array}{l}\text { Nahiz eta ipuina estereotipatua izan, moldake- } \\
\text { tak egiten ditu? } \\
\text { Hizkuntzaren erabilera sexista du? } \\
\text { Nesken eta mutilen parte hartzea orekatuta } \\
\text { dago? } \\
\text { Ez baldin badago, orekatzen saiatzen da? }\end{array}$ \\
\hline
\end{tabular}




\section{Eranskina: IPUINAK SEXISTAK DIREN BEHATZEKO BIGARREN FITXA}

\section{BAI EZ AIPAMENAK}

Protagonista mutilak gailentzen dira?

Emakumezko protagonistek badute izenik?

Emakume eta gizonak parekatuta azaltzen dira?

Zein gailentzen da?

Amona azaltzen da? zertan?

Aitona azaltzen da? zertan?

Zaintza lanetan gailentzen dira emakumeak?

Etxeko lanetan emakumeak gailentzen dira?

Etxetik kanpoko espazioan gizonak dira nagusi?

Lagunekin irteten den emakumerik badago?

Eta gizonik?

Maitasun erromantikoa dago?

Koloreetan estereotipoak bultzatzen dira?

Emakume arrakastatsurik badago?

Eta gizonik?

Emakume ausartik?

Eta gizonik?

Emakume politikaririk?

Eta gizonik?

Emakume kirolaririk?

Eta gizonik? 


\section{Eranskina: GELETAKO IPUINAK: MODU KUANTITATIBOAN AZTERTU DIRENAK}

\section{K1-en gelako ipuinak}

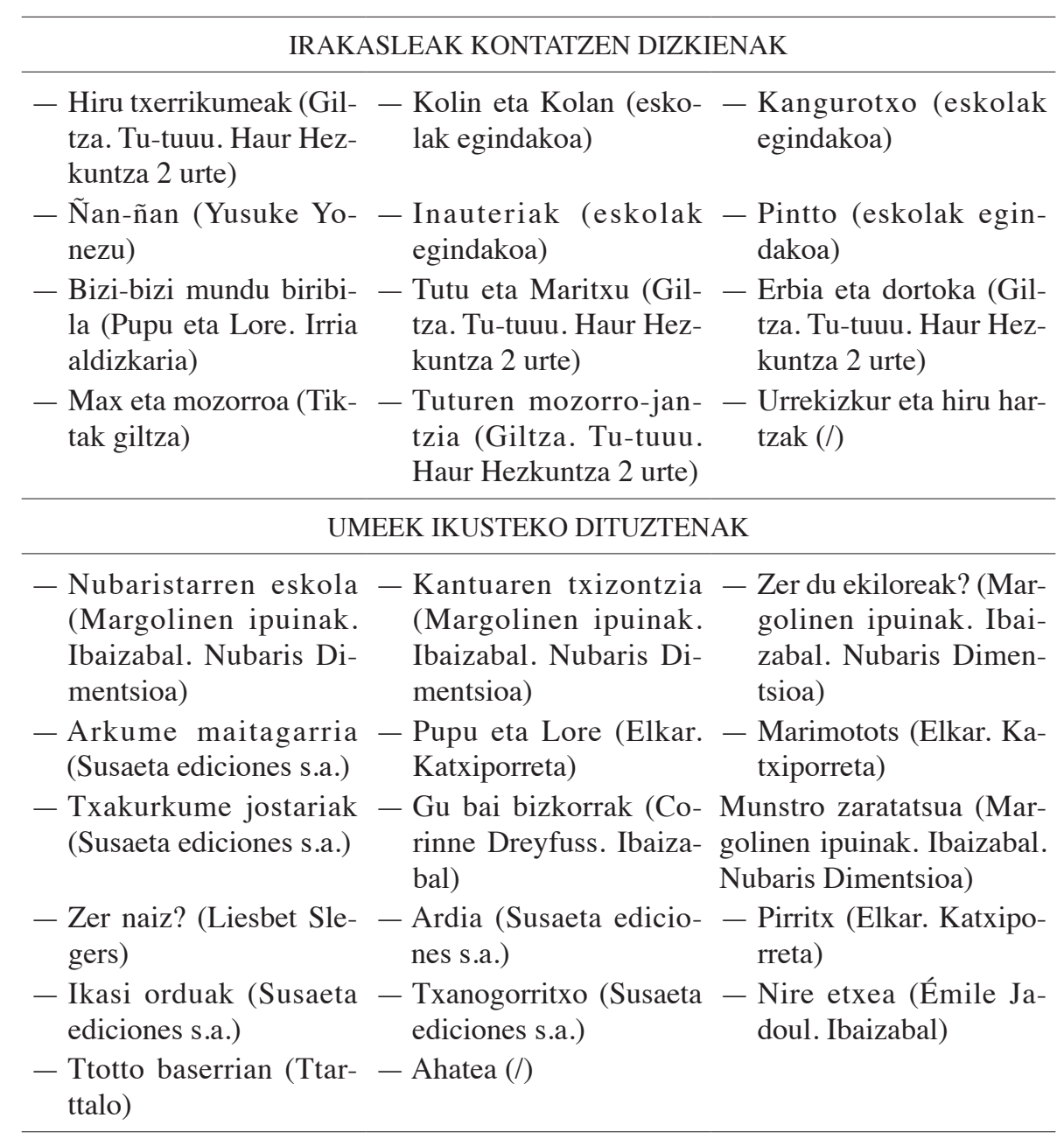




\section{K2-ren gelako ipuinak}

\begin{tabular}{|c|c|c|}
\hline \multicolumn{3}{|c|}{ IRAKASLEAK KONTATZEN DIZKIENAK (Bilduma: Giltza. TIK-TA } \\
\hline Elkarri lagunduz & Lau tximino platanolandian & Artista bikaina \\
\hline Aladin eta kriseilu miragarria & Munstro xelebrea & Gutun lapurra \\
\hline Lagun arriskutsua & Enperadorearen jakintza & Elurretako munstroa \\
\hline \multicolumn{3}{|c|}{ IKASLEEK IKUSTEKO DITUZTENAK } \\
\hline $\begin{array}{l}\text { Basoko animaliak (Sagutxu, } \\
5 \text { bildumak) }\end{array}$ & $\begin{array}{l}\text { Patxi errementaria (Elkarla- } \\
\text { nean, Mari saila) }\end{array}$ & $\begin{array}{l}\text { Gorila (Edición vasca } \\
\text { argitaletxea) }\end{array}$ \\
\hline Hartxu hartza (Hedatu azalak) & Noel Egiptora doa (Edigol) & $\begin{array}{l}\text { Tximas zenbatzen } \\
\text { (Ttarttalo) }\end{array}$ \\
\hline $\begin{array}{l}\text { Ttotto galdu egin da (Ttar- } \\
\text { ttalo) }\end{array}$ & Pasaiako herritik (Xenpelar) & $\begin{array}{l}\text { Tartalo (Elkarlanean, } \\
\text { Mari saila) }\end{array}$ \\
\hline $\begin{array}{l}\text { Kanguroa (Edición vasca ar- } \\
\text { gitaletxea) }\end{array}$ & $\begin{array}{l}\text { Ostruka (Edición vasca ar- } \\
\text { gitaletxea) }\end{array}$ & $\begin{array}{l}\text { Gorila (Edición vasca } \\
\text { argitaletxea) }\end{array}$ \\
\hline $\begin{array}{l}\text { Teo, ikerketan, etxekoabe- } \\
\text { reak (Ttarttalo) }\end{array}$ & $\begin{array}{l}\text { Zapatari txiki (Euskal liburu } \\
\text { eta kantuen argitaldaria, S.A ) }\end{array}$ & \\
\hline
\end{tabular}

\section{K3-en gelako ipuinak}

\begin{tabular}{lll}
\hline \multicolumn{2}{c}{ IRAKASLEAK KONTATZEN DIZKIENAK (Bilduma: Giltza. TIK-TAK) } \\
\hline $\begin{array}{l}\text { Lagundu } \\
\text { Amaiera zoriontsua }\end{array}$ & Itzal tripontzia & Bai mozorro ziztrina \\
$\begin{array}{l}\text { Erbia eta dortoka } \\
\text { Robot berezi-berezia }\end{array}$ & Katu botaduna & Gaueko soinuak \\
\hline \multicolumn{1}{c}{ ETXERA ERAMATEKO DITUZTENAK (Ibaizabal) } \\
\hline Anakleta armiarma & Balduino eta biolina & Benetako altxorra \\
$\begin{array}{l}\text { Daniela dama ederra } \\
\text { Fidel futbolari famatua }\end{array}$ & Edurne elefantea & Rodolfo olagarroa \\
Hermenegildo haserre & Gontzali garrasi egin diote & Simeon sagu sukaldaria \\
& Iñaki ibiltari bikaina & Zarautzeko Olatz ames- \\
Jon eta bere jakin-mina & Kimetz katua & lari \\
Lulu uhartean & Patxi pizzerian & Xixilio xelebrea \\
& & Lagako Leopoldo lepo- \\
Naiaren ahizparen nagikeria & Zorion zoriontsua & okerra \\
Ramon bermeotarra & Patxo txa-txa-txa txapelketan & Timoteo eta Teo trenean \\
\hline
\end{tabular}

